\title{
Mother Labor Participation and Family Education Investment Behavior: An Empirical Study Based on the 2010 Chinese Family Panel Studies (CFPS)
}

\author{
Baokun Dan \\ Department of Economics, Jinan University, Guangzhou, China \\ Email: danbaokun@163.com
}

How to cite this paper: Dan, B.K. (2020) Mother Labor Participation and Family Education Investment Behavior: An Empirical Study Based on the 2010 Chinese Family Panel Studies (CFPS). Modern Econo$m y, 11,62-78$.

https://doi.org/10.4236/me.2020.111007

Received: December 7, 2019

Accepted: January 10, 2020

Published: January 13, 2020

Copyright $\odot 2020$ by author(s) and Scientific Research Publishing Inc. This work is licensed under the Creative Commons Attribution International License (CC BY 4.0).

http://creativecommons.org/licenses/by/4.0/

\begin{abstract}
Parents are the bearers and investors of their children's education expenditures. It is important to discuss the impact of mothers' labor participation on the educational investment behavior of families. Actually. This paper uses the 2010 Chinese Family Panel Studies (CFPS) questionnaire data to conduct an empirical analysis of the impact of mother labor participation on family education investment behavior. The education level of parents is an important factor that affects children's performance, but the labor participation status of mothers affects children's academic performance by affecting family education expenditure.
\end{abstract}

\section{Keywords}

Mother, Labor Participation, Family Education Investment, Academic Performance

\section{Introduction}

Education is the foundation. The education development level of a country is one of the important signs of national prosperity [1]. Since the founding of the People's Republic of China, China's education has made great progress, the popularity of basic education has been rising, the education structure has been continuously improved, and the level of national cultural quality has been continuously improved. However, in general, China's education level is not high, and there is also a great imbalance between regional development, which directly affects China's goal of building a well-off society in an all-round way. 
With the development of China's education industry, the consumption of domestic residents in family education is also increasing year by year [2]. In recent years, the per capita expenditure on education, culture and entertainment in urban and rural areas in China has accounted for more than $10.5 \%$ of total consumption expenditure. In general, there are the following characteristics: There are regional differences in family education investment. The education investment of residents in the central and eastern regions of China is higher than that in the western region [3]. The educational investment behavior of the family is affected by multiple factors, mainly at the family level. Family education investment is developing in a diversified direction [4].

The family is the cell of society, and family education is an important part of the entire educational process. At present, parents are still the bearers and investors of their children's education expenditures. The parents' labor participation status, economic situation, and educational level all affect the family education investment behavior to a certain extent. As a kind of investment in human capital, the main purpose of family education investment is to bring expected benefits to the educated, thereby promoting the improvement of population quality [5].

Therefore, discussing the impact of mothers' labor participation status on educational investment behaviors of families has important practical significance for further understanding of the law of family education investment in China. Only by clarifying the mutual relationship between the two can we better value and optimize the cause of education [6], and provide reference opinions for relevant policies and measures at all levels to promote social prosperity and development.

\section{Literature Review}

The research on family education investment behavior mainly focuses on analyzing its influencing factors. Scholars at home and abroad have done a lot of research on this and published some related papers. Due to the differences between samples and research methods, there are corresponding differences in the research results.

By summarizing and summarizing the existing relevant literature, it is found that the main factors affecting family education investment behavior include: family income, parental education, child gender, number of children, and macro policies. Many influencing factors are mainly concentrated at the household level.

Family education investment is related to family income. In many empirical studies, most consider family income as an important factor affecting family education investment. Schultz [7] found that because individuals are risk-averse and credit constraints exist in the market, even if the rate of return on education is high, the education expenditure of low-income households is still low; Philip H. Brown and other studies believe that Poverty is an important reason for children's academic performance and dropout. 
Family education investment is related to parents' education level and age. Lazear et al. found that in the 1972-1973 US consumer expenditure (CE) survey, parents' education level had a strong positive correlation with family education expenditures; Lloyd et al. [8] found that the education level of the head of household can obviously affect the enrollment rate of girls, but the opposite is true in other countries; Teresa Mauldin [9] and others based on the 1996 US Household Consumption Expenditure (CE) survey on household education expenditure for children aged 6 - 17. The analysis found that the higher the parents' educational level, or the older they are, the more family education expenditures; Huston used the 1990-1991 US Household Consumption Expenditure (CE) data to conclude that parents' education level and age are the impact Factors in household education expenditure.

Family education investment is related to the personal characteristics of children. Lazear et al. [10] found that total household education expenditures increased with the number of children educated, but the gender and age of children did not have a significant effect on family education expenditures, according to the 1972-1973 consumer expenditure of the United States; According to the 1996 US Household Consumption Expenditure (CE) survey, an analysis of the family education expenditure of children aged $6-17$ found that there was no significant correlation between the number of children and the education expenditure of each child; Monazza Aslam [11] etc. In the 2001-2002 Household Income and Expenditure Survey, a comparison of the cost of family education expenditures of boys and girls found that boys have a clear advantage over girls in family education expenditures and schooling opportunities.

\subsection{Research Methods and Ideas}

This research is an empirical study. It follows the idea of combining empirical research and systematic analysis. Based on the analysis and reference of previous research results, it aims to analyze the relationship between mother's labor participation and family education investment, and then explore the mother's labor participation status. Whether it can affect the child's academic performance and draw the role of mothers in family education investment.

To this end, this article uses the 2010 China Family Tracking Survey Questionnaire Data, China Family Panel Studies (CFPS), which collects three levels of data: individuals, families, and communities through tracking, reflecting China's society and economy Data base for changes in population, education, and health.

From the data of the 2010 Chinese Family Tracking Survey, we selected resident families whose children are in the education stage of $6-16$ years old. By analyzing the differences in family education investment concepts and behaviors when mothers have different levels of labor participation, this paper draws the basis of the impact mechanism of mothers labor participation on family education investment, and explores ways to promote more rationalization of family education investment. Viable measures to provide basis for relevant departments. 
This research mainly uses four aspects of the questionnaire content: the first is the basic situation of the family, such as the age of the parents, whether they are employed, the level of education, the gender of the child, etc.; the second is the expenditure of family education investment, including tuition and fees., Book fees, tutoring fees, etc.; the third is the investment behavior of family education, which is mainly reflected in parent-child classes and tutoring classes; the fourth is the academic performance of children. The results of the questionnaire survey were analyzed and analyzed with Stata, trying to analyze the impact of mothers' labor participation on family education investment behavior, and then put forward existing problems and countermeasures.

\subsection{Findings and Innovations}

The impact of mothers' participation in labor on children's family education mainly comes from two aspects [12]: first, the increase in income increases the investment in family education, thereby improving performance; through research, this paper finds that the labor participation status of mothers significantly affects the family's educational investment expenditure, and thus affects the children's academic performance.

In addition, as an innovation, in the empirical analysis, this article adds the cross-term of the mother's labor status and the child's gender as one of the explanatory variables. Is there a difference in marginal effects [13]? The results show that families with mothers working outside are more willing to invest in education for their daughters than families with housewives. It can be considered that working mothers tend to be more independent and better understand the importance of children's education. This will have an impact on the education of the next generation in the form of concept transmission, especially on girls.

\section{Women's Labor Participation at This Stage}

\subsection{Women's Employment Level and Employment Quality in China}

For decades, with the rapid economic growth and structural transformation of our country, China's labor market has undergone tremendous changes, and the employment opportunities and the nature of work faced by women in China have changed dramatically. As one of the ways to achieve self-worth, women's employment helps women to participate more in social activities, and it is of great significance to promote gender equality and social development [14].

Women's employment has always faced many problems and challenges. In 2015, the implementation of the comprehensive two-child policy, and the rising labor costs of female employees in enterprises, made women face more difficulties in the employment process.

Table 1 shows the occupational composition of employed persons in cities and towns by education level and gender. In addition to the female employment 
Table 1. Occupational composition of employed persons in cities and towns by education level and gender.

\begin{tabular}{ccccccccc}
\hline $\begin{array}{c}\text { Education } \\
\text { level }\end{array}$ & Total & Principal & $\begin{array}{c}\text { Technical } \\
\text { staff }\end{array}$ & Staff & $\begin{array}{c}\text { Service } \\
\text { Staff }\end{array}$ & $\begin{array}{c}\text { Agricultural } \\
\text { staff }\end{array}$ & $\begin{array}{c}\text { Equipment } \\
\text { operator }\end{array}$ & Other \\
\hline All & 100.0 & 2.2 & 10.4 & 6.8 & 22.2 & 34.1 & 23.9 & 0.4 \\
Male & 100.0 & 3.0 & 9.1 & 7.8 & 20.1 & 29.3 & 30.4 & 0.4 \\
Female & 100.0 & 1.2 & 11.9 & 5.6 & 24.9 & 40.1 & 16.0 & 0.4 \\
City & 100.0 & 3.6 & 16.1 & 11.5 & 31.0 & 11.8 & 25.4 & 0.6 \\
Male & 100.0 & 4.7 & 13.5 & 12.9 & 26.6 & 10.1 & 31.7 & 0.6 \\
Female & 100.0 & 2.1 & 19.5 & 9.8 & 36.8 & 14.0 & 17.3 & 0.6 \\
\hline
\end{tabular}

rate, measuring the employment level and quality of employment of women can also use the occupational composition of employed persons classified by gender. From the perspective of the gender occupation structure in 2015, whether it is the national or urban employment data, there is a clear difference in the proportion of men and women in employment between unit leaders and operators of production and transportation equipment and related personnel. Among them, among the employed persons in the country, the unit head is male, which accounts for $3.0 \%$ of all employed men, while the female unit head accounts for $1.2 \%$, and men are 2.5 times that of women; and the difference in urban data has slightly eased, Among urban male employed persons, unit heads are $4.7 \%$, women are $2.1 \%$, and men are 2.2 times as many as women. It can be seen that the ratio of the person in charge of the unit is the largest difference between men and women in all occupational structures, and it reflects from the side that women have more obstacles than men to reach the top of the enterprise.

In addition, the indicators of production and transportation equipment operators and related personnel also show obvious differences between men and women, and the employment ratio of men is much higher than that of women. In addition, across the country, as many as $65 \%$ of women are engaged in service and agricultural work, compared with $49.4 \%$ of men. This type of work is characterized by the need for physical exertion or low technical content. Gender differences are common in the classification, and female workers are lower than men in employment levels.

As shown in Table 2. With decades of economic growth and structural transformation, China's employment status composition has also changed dramatically. In 2015, nationwide, $50.9 \%$ of women were self-employed and domestic helpers, compared with $41.7 \%$ of men, a difference of up to $9.2 \%$. At the same time, among the employed people in the country, $52.9 \%$ are male and $46 \%$ are female, and the difference is also large. However, the proportion of male and female employees is almost the same among urban employees, which reflects the rural women in China Employment, is mostly informal employment. Although informal employment can increase workers' income and improve their quality of 
Table 2. Composition of national and urban personnel by age and sex (\%).

\begin{tabular}{cccccc}
\hline & Total & Employee & Employer & Self-employed & Home helper \\
\hline All & 100.0 & 49.8 & 4.4 & 43.2 & 2.7 \\
Male & 100.0 & 52.9 & 5.5 & 40.6 & 1.1 \\
Female & 100.0 & 46.0 & 3.1 & 46.3 & 4.6 \\
City & 100.0 & 67.9 & 6.3 & 22.7 & 3.1 \\
Male & 100.0 & 68.3 & 7.5 & 22.9 & 1.3 \\
Female & 100.0 & 67.3 & 4.7 & 22.5 & 5.5 \\
\hline
\end{tabular}

life, it has the characteristics of poor stability and low social security, which is not conducive to improving the employment status of workers. According to the data, most rural women in China have a higher proportion of informal employment than men, which is not conducive to equal employment between men and women. The status of women's employment is still grim [15].

\subsection{Labor Participation Rate of Females of All Ages in China}

According to the data of the "Sixth Census" in 2010, the employment rate of women in 2010 was 13.8 percentage points lower than that of men. In the past 20 years, the employment rate of women aged 16 to 59 in China has continued to decline, and the gender gap has further expanded. Among the above employees, women account for $44.7 \%$, and the female employment rate is $61.7 \%$; the employment rate for women aged 16 to 59 is $69.9 \%$, indicating that nearly $70 \%$ of urban and rural women of this age in China are engaged in paid social work.

From Figure 1 we can find that perspective of the female labor force participation rate in China, the female labor force participation rate of all ages is in the form of "inverted U". According to the data from the sixth census, the female labor force participation rate increased rapidly during the age of $16-22$ years, then slowly increased and reached the highest value at 42 years old, at $82.80 \%$, and then began to show a significant downward trend. This characteristic does not clearly reflect the change in the employment rate of women in the period of childbearing and child-rearing. The main reason may be that China has a large population and women have a large difference in marriage and childbearing age [16]. In addition, the highest value of women's labor participation rate is at 42 years old, which is more than 10 years away from the 55-year-old female retirement time stipulated in 2010, indicating that there are other factors that hinder women's participation in labor.

\section{Overview of Chinese Family Education Investment}

\subsection{Characteristics of Chinese Family Education Investment}

With the development of education in China, public education expenditure in China has been increasing year by year. Since 2012, China's public education expenditure has accounted for more than $5 \%$ of GDP. 


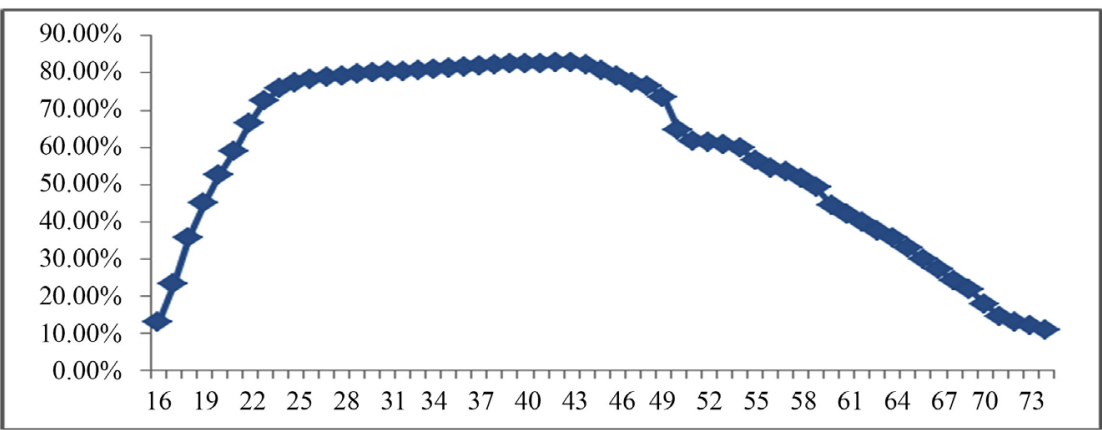

Figure 1. National female employment rate by age in 2010 (\%).

Figure 2 shows that, at the same time, family education consumption in China is also increasing. In 2013 and 2014, the per capita consumption of education, culture, and entertainment in China's urban and rural residents reached more than $10 \%$ of total consumption. According to the research [17], the following characteristics exist in the educational consumption of urban and rural families in China: There is a positive correlation between the investment in family education and the expected return on education investment; Industry, occupation and education level; there are obvious differences in household education investment between different regions, showing that the central and eastern regions are $2-15$ times the western region.

\subsection{Analysis of the Status Quo of Family Education Investment: Based on the 2010 Chinese Family Panel Studies}

\subsubsection{Family Education Investment as a Percentage of Household Income}

In order to learn for their children, most parents are willing to invest in their children's education. The family education expenditure mainly includes tuition and fees, books, extra-curricular tutoring fees, and other expenses such as accommodation and transportation.

In Figure 3, 84.9\% of households spend less than $15 \%$ of their income on education, and $9.5 \%$ of them spend $15 \%-30 \%$ of their income on education. In addition, $1.31 \%$ of the families even spend more on their children's education than their family income. These families are generally in poor economic conditions. Parents use loans and subsidies to make up for their children's education expenses.

\subsubsection{Analysis of Participation in Tutoring Classes}

In Figure 4, with the diversified development of family education investment directions, education expenditure is no longer limited to books, tuition and other expenses. More and more families are asking their children for tutoring, enrolling in tutoring classes, and participating in special interest classes.

As can be seen from Figure 5, most (87.5\%) of the children who have participated in or have participated in tutoring classes/tutors have participated in less than 3 types. Among them, the proportion of children who have participated in 3 tutoring classes/tutors is the highest, accounting for $34.72 \%$. 
Among the many tutoring classes/tutors, foreign language, mathematics, and language tutoring participated in the top three, significantly higher than other subjects, indicating that family education investment is more inclined to intellectual investment, especially the main subject under the education system. In addition, interest classes such as painting and calligraphy, dance, sports, vocal music, and chess are also favored by parents, accounting for $23.5 \%$ of the total, indicating that family education investment is not limited to learning subjects, but also includes the cultivation of specialty areas of interest.

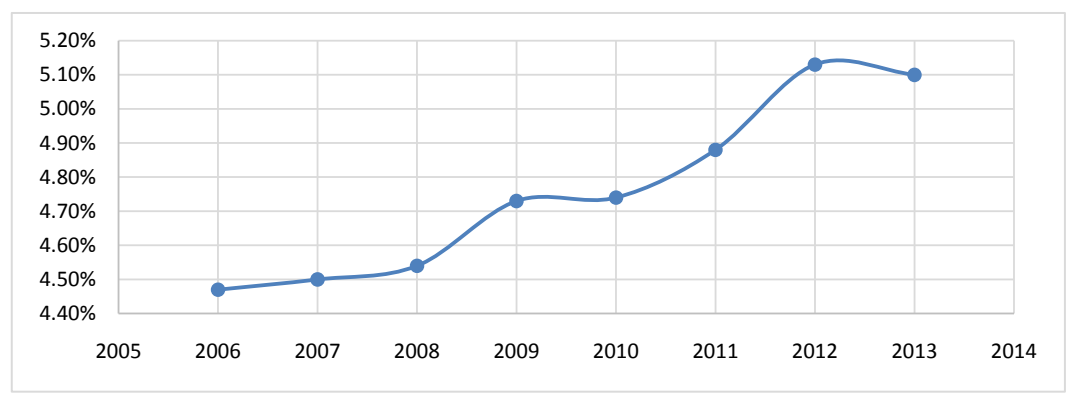

Figure 2. China's public education expenditure as a percentage of GDP.

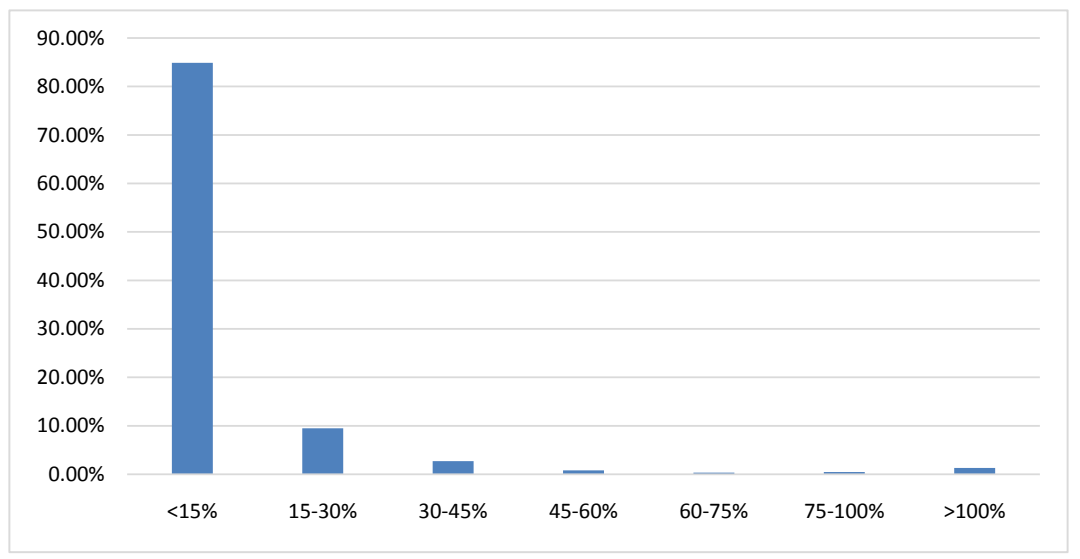

Figure 3. Household education expenditure as a percentage of household income.

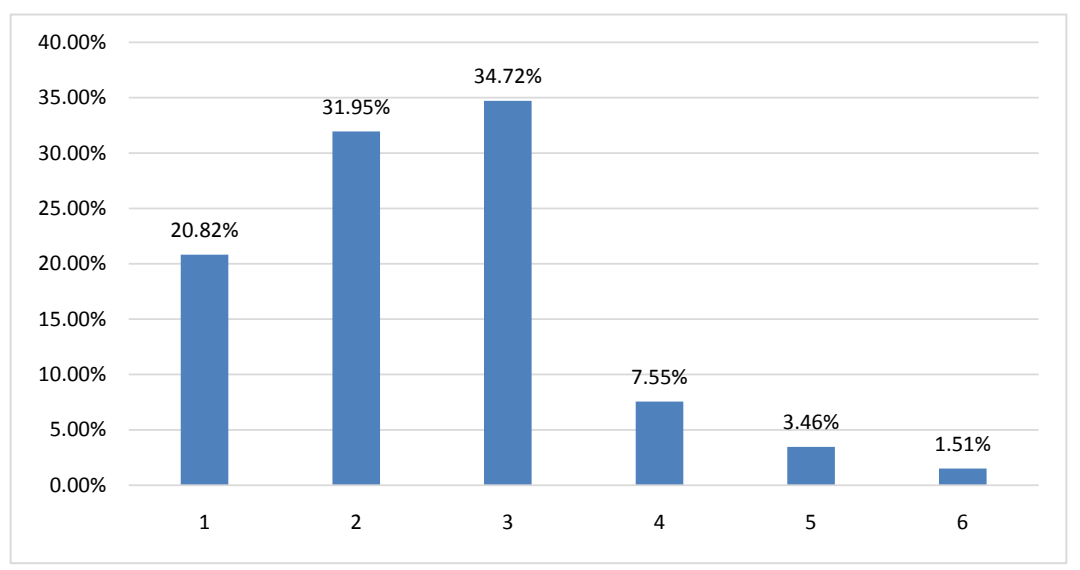

Figure 4. Cumulative number of subjects attended by children who have participated in tutoring/tutoring. 


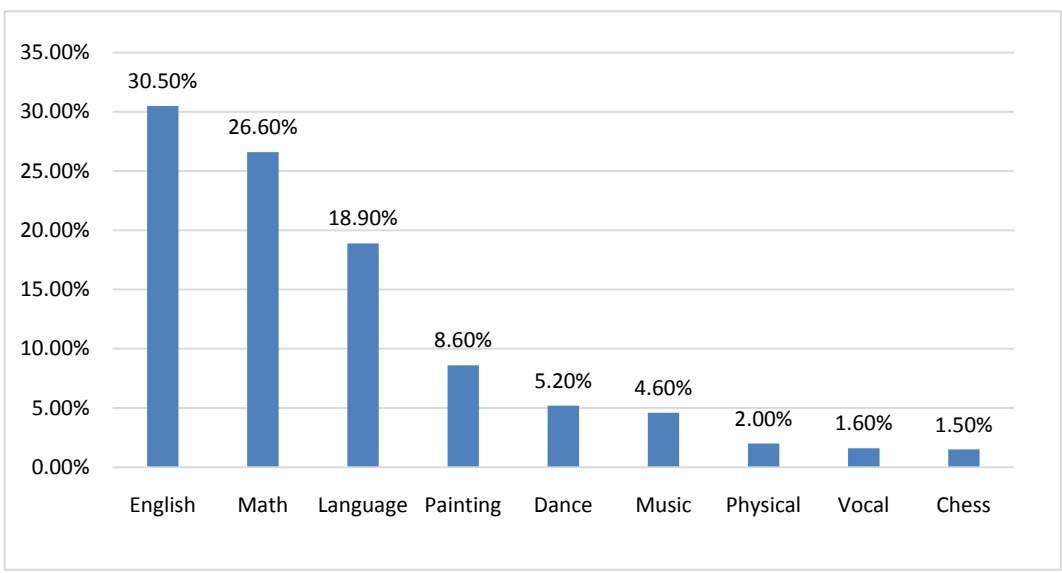

Figure 5. Proportion of subjects participated in all tutorial classes.

\section{Data Processing and Analysis of Empirical Results}

\subsection{Data Processing Instructions}

This article uses data from the 2010 China Family Tracking Survey Questionnaire. The China Family Panel Studies (CFPS) is a three-level survey that collects individuals, families, and communities through tracking, reflecting China's social, economic, population, education, and Changes in health. The CFPS sample covers 25 provinces/municipalities/autonomous regions, with a target sample size of 16,000 households. The survey object includes all family members in the sample households and is divided into adult questionnaires, children's questionnaires, family questionnaires, family relationship papers, and community questionnaires.

Because the purpose of this article is to investigate the impact of mothers' labor participation on family education investment, families whose children are in the education stage should be selected as the research object. First, from the children's questionnaire, first select the children's module ( 6 - 16 years old) questionnaire to obtain a total of 5647 children aged 6 - 16 years; then, match the id of the child's parents with the id in the adult questionnaire to complete after matching, 2785 samples were obtained.

Based on these 2785 sample data, this paper conducts an empirical analysis of the data. The specific ideas are as follows: First, the data is described statistically, the basic situation of the family is described, and the frequency distribution of important indicators is shown in the chart. Second, observe the purpose of education investment and education expenditure of different families, and analyze whether there are differences. Finally, a regression model is used to analyze the variables.

\subsection{Analysis of Empirical Results}

\subsubsection{Impact of Mother Labor Participation on Children's Educational Expectations}

This article needs to explore the impact of mothers' labor participation on family 
education behaviors. Does the employment of mothers affect their expectations of their children's education?

The measure of children's education level is reflected in the questionnaire "What is the highest level you want your child to study?" Table 3 shows the educational expectations of children from families with different mothers' labor participation status. From the data in Table 3, from the perspective of higher education expectations, the proportion of families whose mothers are engaged in employment and their children who want to graduate is $32.25 \%$, which is higher than $25.28 \%$ of those whose mothers are not involved in employment. From the perspective of expectations, whether or not mothers are employed has little difference in their children's education level. And the statistical correlation coefficient between the two is $\mathrm{A}=0.122$, passing the significance test, showing a low correlation.

\subsubsection{Impact of Mother Labor Participation on Total Education Expenditure of Family}

The data of this model is derived from the 2010 Chinese Family Panel Studies (CFPS). By screening children aged 6 - 16 who are currently in the education stage and matching their parental information, 2785 samples were obtained.

The marginal impact of mothers' employment on family education expenditures includes the effects of multiple factors on family education expenditures [18]. For example, mothers' employment includes the impact of increased income on family education expenditures, so it is necessary to add mothers' income as a control variable so that mothers. The marginal impact of employment excludes the impact of mothers' income.

It can be seen from the results in Table 4 that family investment can have an important impact on family education investment expenditure. Among them, the coefficients of whether mothers are employed, mothers' incomes, and fathers' incomes are all positive and significant, indicating that mothers' employment will increase family education expenditures, and parents' incomes have a positive correlation with family education expenditures. This is because family education expenditure is equivalent to squeezing a portion of family income out of education investment for children [19]. Therefore, an increase in family income will cause an increase in family education expenditure, which is consistent with most research conclusions. On average, it is more independent. Compared with housewife-type families, it is more profound and long-term when analyzing and considering problems. It can recognize the importance of children's education for future development, so it is more inclined to invest in family education. It is worth mentioning that the gender of the child has no significant effect on education expenditure, but the cross-term of the employment status of the mother and the child's gender is significant at a significant level of $10 \%$. The impact is greater, and participating mothers are more inclined to invest in education for girls. 
Table 3. Mother labor participation and expectations of children's education.

\begin{tabular}{lllll}
\hline \multirow{2}{*}{$\begin{array}{l}\text { Educational } \\
\text { expectations } \\
\text { for children }\end{array}$} & \multicolumn{3}{l}{ Whether the mother is employed } \\
\cline { 2 - 5 } & Yes & No & \\
\cline { 2 - 5 } & Frequency & Frequency \% & Frequency & Frequency \% \\
\hline Prop out & 0 & 0 & 2 & 0.25 \\
Junior high school & 3 & 0.57 & 20 & 2.49 \\
High school & 3 & 0.57 & 22 & 2.74 \\
College & 26 & 4.96 & 59 & 7.35 \\
Undergraduate & 303 & 3.82 & 47 & 5.85 \\
Master's degree & 49 & 57.82 & 450 & 56.04 \\
PhD & 120 & 9.35 & 43 & 5.35 \\
Total & 524 & 22.9 & 160 & 19.93 \\
\hline
\end{tabular}

Table 4. Empirical model variable influencing factors of household education expenditure and statistical description.

\begin{tabular}{|c|c|c|c|c|c|c|}
\hline $\begin{array}{l}\text { Variable } \\
\text { type }\end{array}$ & Variable name & Variable definitions & Min & Max & Mean & $\begin{array}{l}\text { Standard } \\
\text { deviation }\end{array}$ \\
\hline Dependent & $\begin{array}{l}\text { Education } \\
\text { expenditure (lnexp) }\end{array}$ & $\begin{array}{l}\text { Education expenditure last } \\
\text { year }\end{array}$ & 1.60 & 10.82 & 6.49 & 1.44 \\
\hline \multirow{24}{*}{$\begin{array}{l}\text { Explanatory } \\
\text { variables }\end{array}$} & Family investment & & & & & \\
\hline & ability: & & 0 & 1 & 0.37 & 0.48 \\
\hline & Whether the mother is & $1=$ yes $; 0=$ no & 0 & 13.59 & 8.60 & 1.72 \\
\hline & Employed (work_m) & Mother's annual income & 0 & 1 & 0.57 & 0.49 \\
\hline & $\begin{array}{l}\text { Mother's income } \\
\text { (lnpinc_m) }\end{array}$ & (yuan) & 0 & 13.30 & 9.46 & 1.14 \\
\hline & Whether the father is & $1=$ yes $; 0=$ no & & & & \\
\hline & employed (work_f) & Father's annual income (yuan) & & & & \\
\hline & $\begin{array}{l}\text { Father's income } \\
\text { (lnpinc_f) }\end{array}$ & & & & & \\
\hline & human capital: & & & & & \\
\hline & Mother's degree & 1 = illiteracy; & 1 & 8 & 2.57 & 1.25 \\
\hline & $($ edu_m) & $2=$ primary school; & 1 & 8 & 2.86 & 1.20 \\
\hline & Father's education & 3 = junior high school; & & & & \\
\hline & $\left(e d u \_f\right)$ & 4 = high school; & & & & \\
\hline & & $5=$ College & & & & \\
\hline & & 6 = Undergraduate; & & & & \\
\hline & & $7=$ master's degree $8=\mathrm{PhD}$ & & & & \\
\hline & Investment object & & & & & \\
\hline & Child sex (gender_c) & $1=$ male $0=$ female & 0 & 1 & 0.51 & 0.49 \\
\hline & $\begin{array}{l}\text { Account type } \\
\text { (hukou_c) }\end{array}$ & $1=$ city $; 0=$ rural & 0 & 1 & 0.29 & 0.45 \\
\hline & Cross terms (cross) & \multicolumn{2}{|l|}{$\begin{array}{l}\text { work_mgender_c, Cross-term } 0 \\
\text { between employment of } \\
\text { |mother and child's gender }\end{array}$} & 1 & 0.19 & 0.39 \\
\hline & Mother's age (age_m) & Age of child mother & 21 & 76 & 36.42 & 5.21 \\
\hline & Father's age (age_f) & Child father's age & 36 & 77 & 38.33 & 5.49 \\
\hline & Child's age (age_c) & Child's age & 6 & 15 & 10.43 & 2.93 \\
\hline & $\begin{array}{l}\text { Mother's area } \\
\text { (region_m) }\end{array}$ & $1=$ west $; 2=$ middle $; 3=$ east & 1 & 3 & 2.19 & 0.79 \\
\hline
\end{tabular}

At the same time, the higher the mother's education level, the higher her own quality, the more able she is to invest, and the more she understands the impor- 
tance of knowledge, she is more willing to increase family education spending. There is a negative correlation between the age of mothers and family education expenditure, and young mothers are willing to invest more in their children's education. In addition, children with non-agricultural households are more likely to invest in family education than households with rural hukou [20]. This is because the level of rural economic development and people's income are lower than those in urban areas, and education returns are lower. The more developed the mother's area is, the higher the family's education expenditure is, for similar reasons.

Tutoring education refers to the tutoring and tutoring provided by elementary and middle school students for their cultural lessons or arts in addition to the formal education of the school. An important part of family education consumption is education tuition. According to the questionnaire "How long does the child spend on average in parent-child classes\tutoring classes $\backslash$ tutors (hours)?" To measure the length of the child's tuition per week and explore whether there is a connection with the mother's labor participation. After removing samples of information defects and extreme values, 515 samples were obtained.

From Table 5, it can be seen that the average weekly tutoring time of boys and girls is not much different in the families where the mothers are employed; but in the families where the mothers are not engaged, the average weekly tuition is 9.170, which is significantly higher than the girls 7.601, indicating that there is a significant gender difference in tutoring in families where the mother is not employed, which is manifested in the fact that boys spend more time with tutoring than girls.

\subsubsection{The Impact of Mother Labor Participation on Children's Performance}

It is found from Table 6 that the labor participation of mothers has a significant impact on the total expenditure on family education, and for ordinary families, the expenditure on family education is to improve children's academic performance. In order to investigate whether 2 mothers' labor participation can affect children's performance, we selected the following two questions from the questionnaire to measure children's performance:

1) "As far as you know, what was your child's usual Chinese performance last semester?"

2) “As far as you know, what was your child's usual math performance last semester?"

The impact of mothers' participation in labor on children's performance mainly comes from two aspects: first, the increase in income increases the investment in family education, which improves performance; the second is the increase in the time spent caring for children, which affects children's performance.

So, which mechanism is working, we use the following variables to measure the impact of mothers' participation in labor on children's performance. 
Table 5. Mother labor participation and child tutoring hours.

\begin{tabular}{ccccc}
\hline \multirow{2}{*}{\begin{tabular}{c} 
Extra-curriculum tuition $\begin{array}{c}\text { Whether the mother is employed } \\
\text { for children (hours) }\end{array}$ \\
\cline { 2 - 5 }
\end{tabular}} & \multicolumn{3}{c}{ Yes } & \multicolumn{3}{c}{ No } \\
\cline { 2 - 5 } & Male & Female & Male & Female \\
\hline Mean & 7.180 & 7.794 & 9.170 & 7.601 \\
Standard deviation & 7.670 & 8.063 & 9.847 & 8.171 \\
Min & 1 & 1 & 1 & 1 \\
Max & 56 & 56 & 56 & 43 \\
Total & 144 & 146 & 112 & 113 \\
\hline
\end{tabular}

Table 6. Empirical model variables and statistical description of factors affecting children's performance.

\begin{tabular}{|c|c|c|c|c|c|c|}
\hline Variable type & Variable name & Variable definitions & Min & $\operatorname{Max}$ & Mean & $\begin{array}{l}\text { Standard } \\
\text { deviation }\end{array}$ \\
\hline \multirow[t]{2}{*}{ Dependent } & $\begin{array}{l}\text { Language score } \\
\text { (grade 1) }\end{array}$ & $\begin{array}{l}\text { Parents' evaluation of their } \\
\text { child's usual performance }\end{array}$ & 1 & 4 & 2.81 & 0.94 \\
\hline & $\begin{array}{l}\text { Math scores } \\
\text { (grade 2) }\end{array}$ & $\begin{array}{l}\text { last semester, } 1 \text { = poor; } \\
2 \text { = medium; } 3 \text { = good; } \\
4=\text { excellent }\end{array}$ & 1 & 4 & 2.78 & 1.00 \\
\hline \multirow[t]{20}{*}{$\begin{array}{l}\text { Explanatory } \\
\text { variables }\end{array}$} & $\begin{array}{l}\text { Education expenditure } \\
\text { (lnexp) }\end{array}$ & $\begin{array}{l}\text { Children's total education } \\
\text { expenditure last year (yuan) }\end{array}$ & 1.60 & 10.82 & 6.49 & 1.44 \\
\hline & $\begin{array}{l}\text { Human investment: } \\
\text { Mother taking care of } \\
\text { family time (hourcf1_m) }\end{array}$ & $\begin{array}{l}\text { Working day, Time for } \\
\text { family care (hour) }\end{array}$ & 0 & 13 & 1.61 & 1.90 \\
\hline & $\begin{array}{l}\text { Father taking care of } \\
\text { family time (hourcf1_f) }\end{array}$ & & 0 & 10 & 0.59 & 0.93 \\
\hline & $\begin{array}{l}\text { Family investment } \\
\text { ability: }\end{array}$ & $1=$ yes $; 0=$ no & 0 & 1 & 0.37 & 0.48 \\
\hline & $\begin{array}{l}\text { Whether the mother is } \\
\text { employed (work_m) } \\
\text { Whether the father is } \\
\text { employed (work_f) }\end{array}$ & $1=$ yes $; 0=$ no & 0 & 1 & 0.57 & 0.49 \\
\hline & Human capital: & & & & & \\
\hline & Mother's highest & 1 = illiteracy; & 1 & 8 & 2.57 & 1.25 \\
\hline & education (edu_m) & 2 = primary school; & 1 & 8 & 2.86 & 1.20 \\
\hline & Father's highest & $3=$ junior high school' & & & & \\
\hline & education (edu_f) & 4 = high school; & & & & \\
\hline & & $5=$ College & & & & \\
\hline & & 6 = Undergraduate; & & & & \\
\hline & & 7 = master's degree; & & & & \\
\hline & & $8=\mathrm{PhD}$ & & & & \\
\hline & $\begin{array}{l}\text { Investment target } \\
\text { situation }\end{array}$ & & & & & \\
\hline & Account type (hukou_c) & $1=$ city $; 0=$ rural & 0 & 1 & 0.29 & 0.45 \\
\hline & Child sex (gender_c) & $1=$ male $0=$ female & 0 & 1 & 0.51 & 0.49 \\
\hline & Cross terms (cross) & work_mgender_c, & 0 & 1 & 0.19 & 0.39 \\
\hline & Child's age (age_c) & $\begin{array}{l}\text { Cross-term between } \\
\text { employment of mother }\end{array}$ & & & & \\
\hline & & $\begin{array}{l}\text { and child's gender } \\
\text { Child's age }\end{array}$ & 6 & 15 & 10.43 & 2.93 \\
\hline
\end{tabular}

Similar to the above, a regression analysis method was used to gradually add control variables to verify the effect of mother employment on children's lan- 
guage performance.

From Table 7, it can be seen that family education expenditure can significantly affect children's language performance. It is not difficult to understand that the more parents invest financial resources in their children's learning, the richer the children's learning resources, and accordingly, the more they can promote learning. In addition, the $\mathrm{P}$ value of the variable whether the mother is employed is 0.117 , which failed to pass the significance test. However, in 5.2.2, we have concluded that the employment status of mothers significantly affects family education expenditure, and education expenditure significantly affects children's language. Performance, therefore, believes that mother employment affects the child's language performance to a certain extent.

On the other hand, the educational level of parents has a significant impact on their children's language performance, which is significant at the level of $1 \%$. The higher the parents' educational level, the better the family's learning atmosphere, which has a positive impact on children's academic performance. At the same time, the mother's influence on the child's schooling is more obvious than that of the father.

In addition, children's gender and age also significantly affect their language performance [21]. Girls' language performance tends to be better, and the younger the age, the lower the academic difficulty, which is usually reflected in higher grades. In this article, the child's performance is It is derived from parent's evaluation, so the younger the child, the higher the parent's evaluation of the child's language performance.

Similarly, family education expenditure significantly affects children's math performance. For every $1 \%$ increase in education spending, parents' evaluation of children's math performance increases by 0.056 . Although the employment status of the mother has no significant effect on the children's math performance, we can conclude from 5.2.2 that the employment status of the mother significantly affects family education expenditures, so it can be concluded that the employment status of mothers affects family education expenditures, thereby affecting Child achievement.

In addition, the parents' educational level also significantly affects their children's mathematical performance. The higher the parents' educational level, the better their children's mathematical performance. Compared with the father, the mother has a more significant effect on the child's math performance and has a greater marginal utility.

Different from the above, the child's gender no longer affects mathematics performance, that is, the gender differentiation of mathematics performance is not obvious. In addition, the type of child's household registration also affects their math performance, which has passed the significant level of $10 \%$. The main reason is the uneven distribution of urban and rural teaching resources. Compared to the Chinese language, the teaching of mathematics often requires higher teachers. Children from non-farm households have better math scores. 
Table 7. Probit regression results of factors affecting Chinese performance.

\begin{tabular}{llll}
\hline Variable type & Variable name & Coefficient & P value \\
\hline Dependent & Language score (grade1) & & \\
\hline & Education expenditure (lnexp) & $0.061^{* * *}$ & 0.003 \\
& Whether the mother is employed (work_m) & 0.143 & 0.117 \\
& Mother taking care of family time (hourcf1_m) & 0.021 & 0.206 \\
& Whether the father is employed (work_f) & -0.049 & 0.425 \\
Explanatory & Father taking care of family time (hourcf1_f) & -0.032 & 0.252 \\
variables & Mother's highest education (edu_m) & $0.170^{* * *}$ & 0.000 \\
& Father's highest education (edu_f) & $0.101^{* * *}$ & 0.001 \\
& Account type (hukou_c) & 0.050 & 0.450 \\
& Child sex (gender_c) & $-0.365^{\star * *}$ & 0.000 \\
Observations & Cross terms (cross) & -0.142 & 0.204 \\
Wald chi2(1) & 253.29 & $-0.037^{\star * *}$ & 0.000 \\
Pseudo R2 & 0.061 & & \\
\hline
\end{tabular}

\section{Conclusions}

With the development of education in China, the role of family education becomes more and more important. As an effective way to improve human capital, education has attracted widespread attention. A family's education investment behavior often suffers from multiple effects, mainly from the family level. In this process, the mother's labor participation status played a key role.

For society, the purpose of educational investment is to improve the quality of the population. The research in this paper confirms that mothers' participation in labor can increase children's academic performance by increasing family education expenditures. In addition, as an innovation, in the empirical analysis, this article adds the cross-term of the mother's labor status and the child's gender as one of the explanatory variables. Investing in education has an impact on the education of the next generation in the form of concept transmission, especially on girls.

Therefore, how to encourage women to participate in labor is of great significance for optimizing China's education cause. However, at present, the employment situation of women in our country is not optimistic, manifesting that women's employment rate, employment level and quality of employment are not as good as men's. Therefore, China needs a more comprehensive maternity insurance system and anti-discrimination laws to reduce the impact on women's employment.

\section{Conflicts of Interest}

The author declares no conflicts of interest regarding the publication of this paper.

\section{References}

[1] Zhu, M.L. and Qiao, L.L. (2019) Family Human Capital Investment and Commer- 
cial Insurance Protection. Journal of Finance and Economics, No. 5, 42-52.

[2] Zhang, J.L., Zhang, X.Y. and Yan, D.D. (2019) Research on the Alleviation Effect of Public Education Resources and Family Education Investment on Education Poverty. Journal of Demography, 41, 17-29.

[3] Yu, L.N. (2019) Study on the Investment Preferences and Behaviors of Family Education in the Context of Supply-Side Structural Reforms. Modern Economic Information, No. 21, 419.

[4] Chen, R.J. (2019) A Review of the Effects of Aging on Family Education Investment. Contemporary Economy, No. 10, 148-152.

[5] Lazear, E.P. and Michael, R.T. (1972) Allocation of Income within the Household. The University of Chicago Press, Chicago, IL, 312-316.

[6] Brown, P.H. and Park, A. (2002) Education and Poverty in Rural China. Economics of Education Review, 21, 523-524.

[7] Schultz, T.W. (1990) Human Capital Investment and Urban Competitiveness. American Economic Review, 30, 1-17.

[8] Lloyd, C.B. and Blanc, A.K. (1996) Children's Schooling in Sub-Saharan Africa: the Role of Fathers, Mothers, and Others. Population and Development Review, 22, 265-298. https://doi.org/10.2307/2137435

[9] Mauldin, T., Minmura, Y. and Lino, M. (2001) Parental Expenditures on Children's Education. Journal of Family and Economic Issue, 22, 221-241. https://doi.org/10.1023/A:1016647806016

[10] Hustion, S.J. (1995) The Household Education Expenditure Ratio: Exploring the Importance of Education. American Association of Family and Consumer Sciences, Alexandria, VA, 51-56.

[11] Aslam, M. and Kingdon, G. (2008) Gender and Household Education Expenditure in Pakistan. Applied Economics, 40, 2573-2591. https://doi.org/10.1080/00036840600970252

[12] Gong, J.H. and Zhong, Z.B. (2005) The Impact of Rural Family Income on Educational Investment Behavior of Rural Families-Based on a Survey of Rural Families in Suizhou City, Hubei Province. Statistics Observation, No. 9, 72-74.

[13] Liu, S.Y. (2006) Investment Behavior of Rural Family Education in Shangyi County, Hebei Province. Chinese Academy of Agricultural Sciences, Beijing.

[14] Li, L.R. (2009) Empirical Research on Education Investment Behavior of Urban and Rural Households in Shanghai. Fudan University, Shanghai.

[15] Li, T.P. (2002) Analysis of Urban-rural Differences in Family Human Capital Investment. Society, No. 7, 11-14.

[16] Ni, Y.M. (2001) On Reducing the Burden of Compulsory Education Costs of Households in Poor Areas. Researches in Basic Education, No. 3, 3-5.

[17] Sun, Z.J. (2004) Education Costs, Benefits and Family Education Decisions in Rural China: A Study Based on Gansu Province. Beijing Normal University Press, Beijing, $1-229$.

[18] Yang, L.P. and Song, Y.L. (2007) Logistic Analysis of the Factors Affecting the Willingness to Invest in Education of Rural Families in Western China-Taking Shaanxi Province as an Example. Agricultural Technology \& Economy, No. 5, 60-65.

[19] Wang, Y.W. (2009) Research on Individual Family Education Investment in Social Transformation Period-An Empirical Analysis Based on Survey Data of Chinese Urban Residents. Central China Normal University, Wuhan. 
[20] Zhang, Y.W. (2013) Research on the Current Situation and Influencing Factors of Educational Investment for Dibao Subsidized Families in Shanghai. Master's Thesis, East China University of Science and Technology, Shanghai.

[21] Zhang, Y.H. (2007) Analysis of the Influencing Factors of Rural Human Capital Investment. Journal of China Institute of Labor Relations, 21, 54-58. 